\title{
Does corporate language influence career mobility? Evidence from MNCs in Russia
}

\author{
Marina Latukha ${ }^{\mathrm{a}, ~ *}$, Anna Doleeva ${ }^{\mathrm{c}}$, Maria Järlström ${ }^{\mathrm{d}}$, Tiina Jokinen ${ }^{\mathrm{d}}$, Rebecca Piekkari ${ }^{\mathrm{b}}$ \\ ${ }^{a}$ Graduate School of Management, Saint-Petersburg State University, Organizational Behavior and Human Resource Management Department, The Center \\ for the Study of Emerging Market and Russian Multinational Enterprise, Volkhovskiy Pereulok, 3, 199004 Saint-Petersburg, Russia \\ ${ }^{\mathrm{b}}$ Aalto University, School of Business, Department of Management Studies, P.O. Box 21210, 00076 Aalto, Finland \\ ${ }^{c}$ Graduate School of Management, Saint-Petersburg State University, Volkhovskiy Pereulok, 3, 199004 Saint-Petersburg, Russia \\ d University of Vaasa, Department of Management, P.O. Box 700, FIN-65101 Vaasa, Finland
}

\section{A R T I C L E I N F O}

\section{Article history:}

Received 8 February 2015

Received in revised form

7 December 2015

Accepted 14 December 2015

Available online $\mathrm{xxx}$

\section{Keywords:}

Corporate language

Language skills

Career mobility

Career development

Multinational corporations

Russia

\begin{abstract}
A B S T R A C $T$
The paper investigates how corporate language influences the career mobility of MNC employees in Russia. We apply human capital theory to show how language may be valued in an organizational context. In our work we use a framework that demonstrates that corporate language may act as a glass ceiling. The results show that employees in Russian MNCs with a lower level of corporate language skills will be less likely to consider vertical and horizontal career mobility than employees with a higher level of these language skills. Equally, employees in Russian MNCs with a lower level of corporate language skills will be less likely to consider internal and external career mobility than those employees with a higher level of these language skills. We prove that corporate language may act both as a barrier and as a facilitator for the career mobility of employees in Russian MNCs who have different levels of corporate language skills.
\end{abstract}

(C) 2015 Elsevier Ltd. All rights reserved.

\section{Introduction}

For at least the two most recent decades, academics have been studying the effects of corporate language influence on MNCs (Charles \& Marschan-Piekkari, 2002; Ehrenreich, 2010; Feely \& Harzing, 2004; Lauring \& Selmer, 2011). The theoretical analysis of language comprises a range of studies, which includes theories from the fields of management, sociology, economics, and strategy (Terjesen, Hinger, Tenzer, \& Harzing, 2014). Terjesen et al. (2014) overviewed the existing theoretical background on language and stated that sociological theories mostly focus on culture (in particular, Bourdieu's theory holds a significant place), linguistic distance, and homophyly; social identity power and status characteristics; trust issues; and emotion (Terjesen et al., 2014). Terjesen stated that economic theories include the gravity model, transaction costs, new institutional economics, and human capital theory, whereas strategy theories mostly discuss language and knowledge transfer (Terjesen et al., 2014). Social identity and self-

\footnotetext{
* Corresponding author.

E-mail address: marina.latuha@gsom.pu.ru (M. Latukha).
}

categorization theories are used by language researchers in management to explain why language diversity can separate employees into groups based on a shared language and thus give rise to language boundaries in MNCs (Terjesen et al., 2014). The variety of theories that can be applicable in order to justify language within an organizational context demonstrates the overall importance of the language phenomenon, as it covers a variety of organizational processes in modern companies. A set of papers within both main streams of research have addressed the issue of 'language standardization' and its effects on many organizational functions and processes, in particular external and internal communication (Charles \& Marschan-Piekkari, 2002; Ehrenreich, 2010; Sorensen, 2005), organizational power and control (Vaara, Piekkari, \& Santti, 2005), knowledge transfer (Lauring \& Selmer, 2011; Makela, Kalla, \& Piekkari, 2007; Welch \& Welch, 2008; Welch, Welch, \& Piekkari, 2005), etc. As for the effects of corporate language on international human resource management (IHRM), fewer papers can be found but these frequently state that language is part of human capital: as human capital theory identifies variables are related to employee success (Newburry \& Thakur, 2010). In this sense human capital theory may explain better than other theories how language may be connected with career mobility and thus serve as a framework 
for our research triangle: namely linking language, career issues and MNCs. Even less attention has been attributed to the various dimensions of the effects of corporate language on career mobility and the development of the workforce, and for the careers of individuals who are at different career stages, positions and organizational levels. These are still widely overlooked by researchers (Jokinen, Järlström, \& Piekkari, 2011).

The question of what makes a career successful was raised by Gunz and Peiperl (2007), and they mention that demographic factors such as age and gender, and human capital factors such as working experience and education, are among the most investigated factors influencing career development. In this regard, the factor - corporate language skills and how they (or the lack of them) influence career mobility - which is claimed to be the subject of empirical research analyses (Shanahan, 1996) and has appeared to be a significant part of human capital theory (Becker, 1975; Evans, Pucik, \& Björkman, 2011; Newburry \& Thakur, 2010; Traavik \& Richardsen, 2010), however, actually overlooks the linkage between career issues, linguistic competencies and business processes in MNCs.

Career paths have moved away from traditional, linear career progression (Littleton, Arthur, \& Rousseau, 2000; Peltonen, 1993) to become more multidirectional and unpredictable (Luo \& Shenkar, 2006). They also have become more 'boundaryless' meaning that employees move with greater ease within or between organizations, both vertically and horizontally (Briscoe, Hall, \& Frautschy DeMuth, 2006). There are several qualitative case studies (see, for example, SanAntonio, 1987; Piekkari, Vaara, Tienari, \& Säntti, 2005; Blazejewski, 2006) which have aimed at investigating how a common corporate language shapes, steers and directs the career paths of individual employees in these companies. The cases analyze mostly MNCs located in or originating from developed countries, such as Germany, Finland, Sweden, Denmark and others. However, they neither generalize a large set of data, nor conceptualize a model for a relationship between corporate language and careers. However, there is one study that proposes a theoretical model for this influence (Jokinen et al., 2011), but which still needs to be tested on various MNCs. Moreover, language issues including the relationship between corporate language and career mobility is literally unrevealed for developing countries, in particular for Russia. Thus, this study aims to research how language skills affect employee career mobility in Russia. We formulated our research questions: first, does corporate language act as both a barrier and as a facilitator for the career mobility of employees in MNCs in Russia?; second, do individuals' language skills influence their actual and perceived career mobility in MNCs in Russia?

\section{Theoretical background}

\subsection{Language phenomenon in MNCs and an understanding of it through the lens of human capital theory}

A common corporate language (or a corporate language) is defined by Sorensen (2005) as an important and special 'administrative managerial tool' which is derived from the needs of an international board of directors and top management in an MNC to run global operations. It is expected to grant a common ground for internal communication between business units which are often situated in different language environments as well as external communication between those units and the outer world. An alternative definition of a shared language, or 'lingua franca' could be expressed as a communication tool between employees who are native and non-native speakers (Tietze, 2008), in an organizational context it is referred to as a corporate language (Marschan-Piekkari, Welch, \& Welch, 1999a), and is considered to be part of the human capital of a company (Newburry \& Thakur, 2010; Traavik \& Richardsen, 2010).

At the same time, a MNC is a multilingual organization and this has been highlighted by several scholars. For example, some of them argue that MNCs are not usual companies and they are multilingual almost by definition, and that is why the introduction of a common corporate language will not render the firm monolingual, as language diversity within a global firm is likely to persist (Marschan-Piekkari et al., 1999a, b; Sorensen, 2005). The common corporate language is often supplemented with so called "company speak', in other words with particular abbreviations and expressions reflecting the culture of the company in question and its way of operating (Welch et al., 2005). In addition, various groups of personnel have their own professional language taken from respective communities of practice that are brought to the workplace creating a human capital pool within an organization. We identify a set of arguments, which question the position of the common corporate language as a "shared language". These arguments are associated with the multilingual nature of the MNC, the language competence among its employees, and the level of analysis used (Fredriksson, Barner-Rasmussen, \& Piekkari, 2006). The ambiguity of the common corporate language may be associated with language competence among a MNC's staff.

Human capital theory refers to employees' competences (different knowledge and skills) (Evans et al., 2011), and can be proved to include language competence (Traavik \& Richardsen, 2010). As human capital corresponds to any set of knowledge or characteristics of an employee (Becker, 1975), the role of language in any firms' operations reveals important, and has influencing, power. By only claiming that any language can be a common corporate one neither helps employees to be more proficient in it (Piekkari \& Zander, 2005; Pohjanen \& Talja, 2011) nor enhances their human capital. Those whose professional role requires crossborder information sharing show variable levels of language competence; equally, employees at the lower levels of organizational hierarchy are more likely to speak only the local language. It always takes time before language competence in the common corporate penetrates the entire MNC (Bjorkman \& Piekkari, 2009) and becomes human capital at an organizational level.

In response to the demands of operating in multiple foreignlanguage environments and having noticed all the benefits that a common corporate language brings, many MNCs have adopted it with the intention of facilitating the process of in-house as well as customer communications. Among such multinational corporations are General Electric (origins in USA), L'Oreal (France), Nokia, Kone (Finland), Siemens (Germany), Electrolux, Nordea (Sweden) and many others. In most cases, English has been established as the lingua franca (or 'shared language') to help different employees who are either native or non-native speakers to communicate effectively (Tietze, 2008).

The important role of corporate language as a tool for international knowledge transfer is also reviewed in several papers (Buckley, Carter, Clegg, \& Tan, 2005; Makela et al., 2007; Welch \& Welch, 2008). The purpose of the researches was to draw attention to the various ways language affects the process of international knowledge transfer, and in the course of the analysis, the authors found that there is a pervasive and dynamic influence of language acting as a powerful reconfiguration agent (Welch \& Welch, 2008), which further emphasizes human capital development (Newburry \& Thakur, 2010). The other research studied four MNCs located in China, on the role of common corporate language in the process of knowledge transfer from a country of origin to an overseas subsidiary. It proved the high importance of this process together with the necessity of possessing an adequate level of common language skills for increased success (Buckley et al., 2005). 
Makela et al. (2007), in their research, observed a shared language as one of the crucial conditions for knowledge sharing within clusters in MNCs and for creating specific human capital within an organization.

The other branch of studies in this field investigates common corporate language benefits for exporting companies (Clarke, 2000; Crick, 1999; Cromie, Clarke, \& Cromie, 1997). Crick (1999) analyzes the use of language in the export operations of many firms (mostly SMEs) and finds out that the importance of language for exporters, as representatives of international companies, is high. Crick (1999) states that companies do not use other languages a great deal, due to the fact that English was widely spoken in business naturally, as explained by the interviewees. Regardless of what exporting companies say about having an official corporate language, the studies show that they win when using foreign languages differing from the language of their origin. Clarke's investigation (2000) finds out that in some cases foreign language skills may contribute to success in different export operations and noted that $86 \%$ of respondents stated that it was 'important', 'very important' or 'essential' to be able to understand the language of their export customers (Clarke, 2000). Nevertheless, the study also shows that two thirds of those companies conduct their export business entirely in English (Clarke, 2000). This example shows that exporters recognize the high importance of language in their international operations, which can lead us to the question of their corporate language choice. Feely and Harzing (2003) also think that MNCs make the choice concerning official corporate language in order to ease communication within and outside the company. According to their study, a prime reason for a common corporate language is to make information flow efficiently within the company in, for example, formal reporting, information systems and cross-national interaction. From this perspective, we prove that language may contribute significantly in human capital development, in an organizational context, as human capital increases an employee's productivity in different tasks, organizations, and situations and business process (Becker, 1975; Traavik \& Richardsen, 2010). Moreover, the researchers raise the question of uncertainty concerning which language should be used in the circumstance of communication between two subsidiaries in different language environments. Having an established corporate language, employees thus know that, as a rule, in common communication one official language can be used (Feely \& Harzing, 2003; Henderson, 2005).

In IHRM studies language is observed in the process of a shift from a domestic human resource management (HRM) strategy to IHRM strategy (Plessis \& Huntley, 2009). Obviously, when a company decides to change the focus of its human resources practices towards an international approach it must consider the factor of language differences, which makes the international scene more complex (Plessis \& Huntley, 2009). The importance of foreign language competencies is highlighted by Turnbull and Welham (1985), who argue that they influence buyer-seller interaction, establish trust, and indicate commitment and respect for the customer. These findings are echoed by Swift (1991), who argues that foreign language competencies shape the relationship and help to understand the foreign business context (Swift, 1991). Marschan-Piekkari et al. (1999a) deal with additional effects caused by the introduction of a common corporate language in such IHRM functions as staff selection, training and development, and international assignments. According to Becker (1975), one of the important goals of human capital is knowledge gained through training, which adds additional value to human resource development. Charles (2006) mentions an overall international HRM function as greatly affected by corporate language policies. It is crucial to mention that most of the research on the topic looks at the existence of corporate language in a MNC in which a certain and sufficient level of corporate language competence in a firm was assumed, while it would be reasonable to also assume that the level of the mentioned effects on MNCs may be strongly dependent on the level of corporate language proficiency among personnel. Moreover, human capital theory (Becker, 1975) says that workers can have different amounts of skills/human capital because of innate differences that may explain differences in employees' language competencies. Some works take this factor into consideration (Andersen \& Rasmussen, 2002; Bjorkman \& Piekkari, 2009; Ku \& Zussman, 2010; Marschan-Piekkari, Welch, \& Welch, 1997, 1999b; Pohjanen \& Talja, 2011). The language competence of multinationals in the present day must develop in order to meet the increasingly diverse challenges of the global business environment (Pohjanen \& Talja, 2011) but this depends on a particular set of human capital within an organization (Evans et al., 2011).

To continue our analysis from the human capital theory perspective (Becker, 1975), the level of an individual's investment in competencies' development determine an employee's level of performance, and affect career opportunities. Empirical studies prove that human capital factors impact career success (Judge, Cable, Boudreau, \& Bretz, 1995; Ng, Eby, Sorensen, \& Feldman, 2005) whereas language plays a significant role. In recent years the employee requirement for becoming proficient in corporate language was pushed further down the hierarchy to a diminished level of importance. Once a common corporate language has been established, it becomes an important entry path to corporate training and management development programs, potential international assignments, and promotion, as figured out in the case study of a Finnish MNC by Marschan-Piekkari (Marshan-Piekkari et al., 1999a). An important incentive to learn corporate language is thereby created. For those who do not acquire competence in the common language, there will be virtually no opportunities to participate in company-wide activities and they will remain confined to their local operations (Marshan-Piekkari et al., 1999a). This article argues that the corporate language skills of employees in MNCs located in Russia affect their career opportunities; in some way this has been shown to be an influence in the developed countries examined.

\subsection{Corporate language as a factor for career mobility}

Career mobility is usually defined as individual job change cycles in an employee's personal life (Hegedus \& Haman, 1992). Some researches argue that human capital factors influence career objectives and mobility (Judge et al., 1995; Newburry \& Thakur, 2010; $\mathrm{Ng}$ et al., 2005) and can be explored from two different perspectives: horizontal and vertical mobility (Marschan-Piekkari, Welch, \& Welch, 1999b). This means, according to Ibarra (2002), that career mobility may be towards a position that is higher or similar to a job in the same field. The authors refer to horizontality in career mobility as moving sideways within an organization's hierarchy, for example, to different assignments, to different departments without being promoted upward. Verticality in career mobility means, on the contrary, moving up in an organization's hierarchy to more responsible positions, for example, to become a specialist expert, or to supervisory and managerial jobs (Marschan-Piekkari et al. 1999b). Feldman and $\mathrm{Ng}$ (2007) stated that to understand career mobility, it is important to understand how job, organizational and occupational embeddedness affect career success. Following this, career mobility can be connected with individual and environmental factors (Ituma \& Simpson, 2009). It is argued that career mobility is affected by internal factors (Khapova, Arthur, Wilderom, \& Svensson, 2007) and external factors, such as family, society, work-force supply and demand (Barnett \& Miner, 1992; 
Dobrey, 2005; Forrier, Sels, \& Stynen, 2009). Moreover, Ng et al.'s (2005) framework suggested that organizational, sociodemographic, stable individual difference, human capital, motivation and social capital factors affect career success and mobility.

There is also the other categorization used by some researchers: physical (or actual) and psychological (or perceived) career mobility (Marschan-Piekkari et al. 1999b). The former means actual career moves that an individual has already done or is going to do, and the latter shows perceived preparedness and willingness to make a career in the future (Baruch, Grimland, \& Vigoda-Gadot, 2014). To discuss this in more detail, some researches argue that whereas physical mobility concerns changing job positions, psychological mobility refers to a person's preference to cross boundaries (Lazarova \& Taylor, 2009; Marler, Barringer, \& Milkovich, 2003), and also as the perceived capability to move (Arthur, Khapova, \& Wilderom, 2005; Sullivan \& Arthur, 2006). Sullivan and Arthur (2006) identified psychological mobility as an individual's perceptions of career paths and a certain belief of the possibilities of a person following them. Psychological mobility is described along two dimensions: organizational mobility preferences and a boundaryless mindset of one's general attitude to working across organizational boundaries (Briscoe, Hall, \& Frautschy DeMuth, 2006; 2012). It can be argued that for individuals pursuing boundaryless careers, flexible rather than firmspecific human capital (knowledge) that is applicable in different organizational contexts and boundaries is important (DeFillippi \& Arthur, 1994; Eby, Butts, \& Lockwood, 2003). This view of psychological mobility has been adopted in certain recent studies of contemporary careers (Briscoe \& Finkelstain, 2009; Briscoe, Henagan, Burton, \& Murphy, 2012; Verbrugge, 2012), and connected with career success, whereas career success is linked with external benefits such as promotions, changes in rewarding, and the level of competencies development (Judge \& Hurst, 2008; Seibert, Kraimer, \& Liden, 2001), which is connected with the level of human capital. From this point of view organizational mobility preferences may have an important connection with corporate language due to the necessity for an employee to have particular personal and managerial competencies even in the situation of a perceived or planned career path. From an organizational perspective, individuals' career successes are vital for a firm's success, due to the linkage of employees' results with company's performance ( $\mathrm{Ng}$ et al., 2005), whereas the role of the organization is to support, enable and develop its human assets and human capital (Baruch, 2006; Becker, 1975). From this angle, language competence as a part of human capital is viewed as an important organizational resource (Bloch, 1995) and a strategic characteristic of a career (Luo \& Shenkar, 2006). Returning to the discussion of internal factors that influence career mobility and their connection with the language phenomenon, we argue that such factors may create a background for language competencies and in some cases form it. From the other perspective, external factors are also connected with language as, for example, family and society push a person to obtain, or not, particular language skills. Thus, Nousiainen (2011) concludes that the corporate language strategy of a certain firm can be perceived as a facilitator for career mobility within a MNC in the case of an individual possessing those language skills. On the contrary, if they do not have those skills, a corporate language strategy becomes a barrier for career mobility, which can be overcome by learning the language. From the human capital theory perspective, we note that training and career development perspectives may be considered as valuable managerial practice. Indeed, language competencies in turn impact career success including recruitment, career perspectives and mobility within organizations, as well as perceived career success more directly (Lönnholm, 2012). Language competence affects objective career success also through influencing the ability of an employee to build relationships, gain access to information and advice, and achieve a higher informal status in the organization (Lönnholm, 2012). Moreover, language competencies may also have impact on career success through affecting employees' perceptions of their own competence, which also contribute to an individual's perception of career success (Lönnholm, 2012; Peluchette, 1993).

The other way that corporate language influences career mobility appears to be rather negative. The issue is that this concept does not consider the importance of communication, information exchange and networks that are already in local languages in many business units of a MNC. Thus, additional language skills may be unofficially necessary for employees to become entirely part of a local environment and this requirement can present a more serious language barrier for career mobility than the common corporate language strategy itself (Nousiainen, 2011). This inference is proved by the research conducted by Muukari (2008) on a Swedish bank in Finland. The established corporate language of the bank was Swedish and it acted as a push factor for employees, who lacked Swedish language skills, to leave the firm even though they might be professionally more capable than those who stayed.

There are qualitative case studies (Blazejewski, 2006; Piekkari et al., 2005; SanAntonio, 1987) which aimed at investigating how a common corporate language shapes, steers and directs the career paths of the individual employees of those companies. For example, Blazejewski (2006), having studied a German-owned subsidiary located in Japan, has found strong proof that English as a common corporate language seriously interfered with an established organizational structure and favored younger managers over senior ones. There were cases in which younger inexperienced employees climbed up the corporate ladder faster than their senior colleagues. This occurred despite the Japanese traditional hierarchy in organizations based on seniority, formality and professional experience, because younger managers more frequently used English in communication with the English-speaking top management. The other case study (Piekkari et al., 2005) of a Nordic financial institution, formed as a merger, has shown that the introduction of Swedish as a common corporate language effectively removed the possibilities for non-Swedish speakers to be moved upward in the organizational structure in a Finland-based subsidiary. This paper also primarily mentions a corporate language acting as a 'glass ceiling' for both vertical and horizontal career mobility of individuals in MNCs.

There is one more potentially negative effect of a corporate language on career development. As demonstrated in Muukari's research (2008), sometimes the established corporate language impacts the firm's image and may influence an applicant's decision on whether to apply for a position in that company or not, depending on whether they possess the appropriate language skills or not. The findings of Muukari's single case study research were that $37 \%$ of Finnish employees working in the Finnish subsidiary of the Swedish company, evaluated that their Swedish skills were 'good'. Thus, the author states that the applying to the Finnish subsidiary by people with Swedish language skills was encouraged by the existence of a corporate language and a desire to use and be appreciated for that skill. Accordingly, the influence of corporate language on the firm's image is evaluated as 'strong' in that it impacts the applicants' decisions depending on whether they have those language skills, or not, thus preventing psychological career mobility (Piekkari et al., 2005).

From the evidence given by the researchers mentioned above, it could be assumed that to a large extent the overall corporate language of a firm may have positive and negative effects on the career mobility of employees in MNCs, vertically and horizontally as well as physically and psychologically. 
Piekkari (2008) mentioned that while several researchers concluded that the requirements for employees' language skills in MNCs have been raised recently, the exact reason why and how those skills influence career mobility is still lacking. An employee's language skills may facilitate career mobility within the company both horizontally and vertically. These impacts can be seen in some limitations placed on the ability of linguistically incompetent employees to participate in educational programs and international assignments (Marschan-Piekkari et al., 1999b). Besides, there is little research devoted to the influence of the absence of language skills. For example, it may leave certain positions outside of the employees' capabilities and reach; however, this hypothesis requires more research. The work of Piekkari (2008) states that international mergers and acquisitions that constantly shape the business have shifted focus from solely professional skills towards requirements on language capabilities. At the same time, despite the fact that corporate language skills can open doors to many opportunities, the importance of having just corporate language skills for career mobility is still seen narrowly (Nousiainen, 2011).

To conclude, the reviewed existing theories clearly highlight that language, as an element of an individual's human capital, can have a role to play in an individual's subjective career success.

\subsection{Corporate language as a glass ceiling for career mobility}

It may be inferred that a corporate language strategy may have its effect on an individual's actual and perceived career mobility both horizontally and vertically, sometimes acting as a so-called 'glass ceiling' (Piekkari et al., 2005). The research (Piekkari et al., 2005) discusses the corporate language skills of employees in MNCs not only as part of organizational human capital, but more as an enabler or barrier for individual career mobility. The same authors, based on the knowledge and arguments from the previous research on the topic, have framed their ideas into a model in a more recent paper (Jokinen et al., 2011). The concept of glass ceiling was introduced to describe promotion limitations in the career development field (Hege \& Ralston, 1993) and now is more often connected with linguistic competences (Huang, Frideger, \& Pearce, 2014). Research in the MNC context proves the existing effect that language may have on an individual's promotion prospects by acting as a linguistic glass ceiling (Piekkari et al., 2005), preventing individuals that are not well versed in a certain language or certain languages from vertically advancing in the company (Lönnholm, 2012). There are a few researches devoted specifically to the corporate language influence on the career mobility of individuals as an external boundary in several individual MNCs, yet, they neither generalize a large set of data nor conceptualize a model of this relationship. Moreover, these papers analyze companies located in developed countries, such as Finland, Sweden, Germany, Japan, UK, Ireland, etc., while none have studied the situation in the developing world (except China), for example, Russia.

The following figure illustrates how corporate language may act the role of glass ceiling for career mobility for employees in MNCs (Fig. 1).

The framework illustrates a MNC as a triangle penetrated by corporate language (organizational factors). The model assumes that a common corporate language may act as a glass ceiling (not only vertically but also horizontally) for career mobility in a case in which an individual's skills (individual factor) do not fit the corporate language. Those people who speak the corporate language are depicted as squares with corporate language (CL) annotated inside; those who lack these skills are depicted as circles with local language (LL) annotated inside. This framework describes an overall possible relationship between corporate language in a MNC and the career mobility of its employees, which is the main focus of

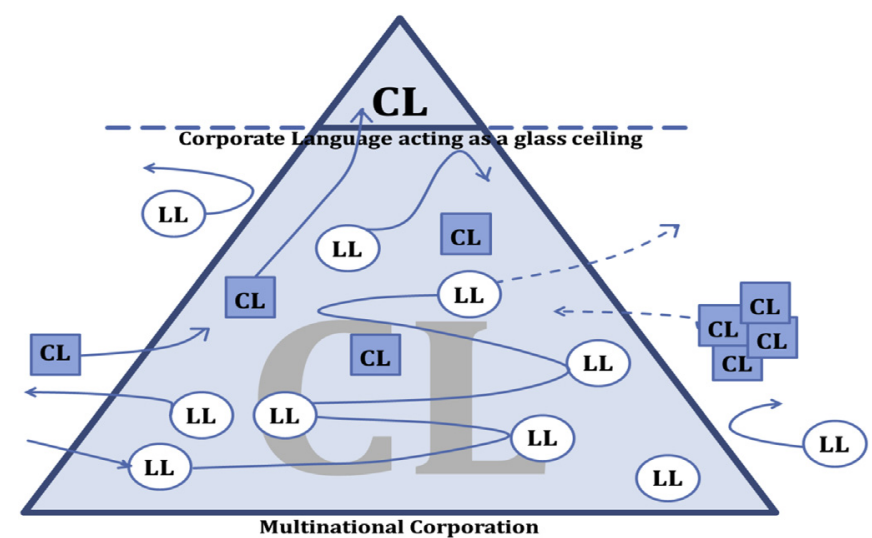

Fig. 1. Corporate language acting as a glass ceiling. Source: adapted from Jokinen et al., 2011.

this paper. This framework was selected for the current research with the intention of it being tested and conclusions being made in the context of MNCs in Russia.

As for the current situation in Russia, few works can be found devoted to language issues in international organizations in Russia. Russia as a subject for research is often overshadowed by the more remarkable rise of companies in China and India (Filippov, 2009), and when academics pay their attention to Russia, they usually investigate motives and strategies of MNCs' internationalization (Filippov, 2009), or foreign market entry strategies and post-entry operations (Panibratov, 2012). Some studies just mention language as an obstacle for Russian MNCs' operations in Poland. Klevtsova (2008) in her article about English language training for personnel says that English as a recognized international business language is becoming a must for almost all middle and top management candidates, but she also notices that a much lower percentage of pre-existing working employees have this language skill, which creates communication and efficiency problems at work. Language competencies of employees in Russian companies are usually not the focus of training and development programs if there is not a case for expatriate preparation. In the Soviet period, English as a language for communications in an organizational context was not important due to the limited international operations of Russian firms worldwide, and it was not studied on a mass level. This fact created a number of employees in the Russian labor market who do not currently have any foreign language competence but are still considered to be people of an appropriate working age. During the last $10-15$ years the value of foreign language competencies was reconsidered due to the large numbers of MNCs that entered the Russian market with the particular requirements to speak English as a corporate language: during this time language has begun to be considered apart of human capital in the Russian context. One of the most interesting factors that actually limits language competencies' development in the Russian context is the fact that MNCs' subsidiaries use Russian as a corporate language even if the top management is an English speaking team. Language for day-to-day communications in the business context, for both Russian and foreign companies operating in Russia, is Russian. Despite this fact, English is still used basically more often by young graduates or middle-aged employees who intend for middle management or top management positions within foreign MNCs or are looking for a job abroad. Depending on the corporate language in a MNC, it acts both as a barrier and as a facilitator for an individual's career mobility. The most obvious disparity is when corporate language differs from the native language of that country. If a MNC has formal requirements for its 
current and potential employees this may be viewed as a career facilitator within that MNC in the case of an individual speaking that language and vice versa, if they do not possess that skill, a corporate language may be viewed as a barrier for career mobility. At the same time, if an individual does not have corporate language skills, they obtain them by learning the language and thus, removing a language barrier for their career development. Moreover, a corporate language becomes a pull factor for candidates applying to a company if they possess corporate language skills. Vice versa, it may become a push factor in leaving an organization, in the case of those lacking that skill (Muukari, 2008). In the circumstance of more than one corporate language being used in a company, possessing (or obtaining) competence in those languages is perceived as a career facilitator due to a clear language strategy seen by current and potential employees. However, from the perspective of an individual, who lacks competence in at least one of the required languages, this affects visible career opportunities, and seems to be an obstacle and obstruction. Although the influence of an individual's language competence is not widely studied by researches (Nousiainen, 2011), and the exact reason why and how language skills affect an employee's career is still lacking (Piekkari, 2008), it was found that they give enhanced opportunities for building a network (Lauring \& Selmer, 2011) that, in turn, positively impact career mobility and success, as in some cases a career opportunity proceeds not only from an employee's own skills but also from the 'correct' people they know. Therefore, it is possible to assume that an individual's language skills help them to build a more successful career and become human capital in organizational settings.

The fore-mentioned framework allows for the development of several research questions, which each touch on corporate language issues (both from a company perspective as a corporate language strategy and an individual perspective as personal language skills) for career mobility of different types (vertical and horizontal; internal and external; physical and psychological) in MNCs in Russia. Based on this discussion, we argue that the framework can be applicable for MNCs in Russia. As the previous language research was conducted on international companies in developed countries, it would be of high interest to see what the influence of corporate language in Russia is.

To answer our research questions we formulated four propositions to guide us in the empirical part:

Proposition 1. Employees, in Russian MNCs, with a lower level of corporate language skills will be less likely to consider vertical career mobility than employees with a higher level of these language skills.

Proposition 2. Employees, in Russian MNCs, with a lower level of corporate language skills will be less likely to consider horizontal career mobility than employees with a higher level of these language skills.

Proposition 3. Employees, in Russian MNCs, with a lower level of corporate language skills will be less likely to consider internal career mobility than those employees with a higher level of these language skills.

Proposition 4. Employees, in Russian MNCs, with a lower level of corporate language skills will be less likely to consider external career mobility than those employees with a higher level of these language skills.

\section{Method}

Our theoretical analysis identified the need for empirical research in the Russian context. To test a chosen framework, a questionnaire was developed consisting of seven logical parts and covering all aspects of the research questions. After a validation of the questionnaire and placing it online on a specialized web platform, a survey was conducted among managers of different levels and specialists working in various MNCs in Russia. Entrepreneurs were excluded from the sample, not being within the target of the current research. The survey was translated into Russian for the respondents in order to let them answer the questions in their mother tongue and to minimize misunderstanding among respondents. The data concerning MNCs in Russia was collected in the period 2012-2013. The survey was sent by e-mail with a short description of the topic and purposes of the study and reminders were sent again two weeks and three weeks after the first invitation in order to increase the response rate.

The survey consisted of seven logical parts: 1 . General career perceptions; 2. Language skills; 3. Language skills and career; 4. Career mobility; 5 . Work and career satisfaction; 6 . Career enablers and hindrances; and 7. Demographics. The most crucial terms (such as horizontal and vertical career mobility, native language, foreign language, and corporate language) were explained in the questionnaire in order to avoid misunderstandings being made by the respondents. In practice, physical (or actual) career mobility is easier to estimate than a psychological (or perceived) career mobility, as there are several clear factors to measure the former: actual position, number of promotions, advancement, salary level, etc. The measures for investigating the latter have been developed only recently (Jokinen et al., 2011). Concerning physical (actual) mobility, the academics suggest paying attention to different aspects of it, including the direction (upward, downward or sideward), duration (short-term or long-term), reason (voluntary or forced), and origin (assigned or self-initiated). In this research, the focus is on both physical (actual) and psychological (perceived) career mobility and that is why overall preparedness and willingness of each respondent to take a move in their career is investigated through the survey. The direction of mobility (vertical or horizontal, and within or outside an organization) is also important in answering the research questions and is taken into account in the survey.

In the main body of the questionnaire the majority of questions were built on a bipolar scaling method - a seven-level Likert-type scale (Likert, 1932). Responding to this kind of a questionnaire item, the respondents should have specified their level of agreement or disagreement for a series of statements according to a symmetric 'agree-disagree', scale. The scale had seven levels ( 1 - absolutely disagree; 2 - mostly disagree; 3 - somewhat disagree; 4 - neutral; 5 - somewhat agree; 6 - mostly agree; 7 - absolutely agree). Likert scaling assumes that the distances between each item are equal. So, the proposed range captured the intensity of respondents' feelings for a certain statement (Trochim, 2002), and thus, enables a deeper analysis of the subject. The first (General career perceptions), third (Language skills and career), fourth (Career mobility) and fifth (Work and career satisfaction) parts of the questionnaire were built with these kind of items. The Likert-type scale was also used as a base to build another type of question (third, fifth, sixth parts of the questionnaire) ranging the possible answers in seven levels from minimum to maximum meaning. For example, there is a set of questions analyzing the meaning of foreign language skills in career development, whereby a respondent is offered to indicate the significance of meaning ( 1 - no meaning at all ... 7 - very large meaning). A similar structure of questions was used when analyzing career enablers and hindrances $(1-$ a big hindrance ... 7 - a big enabler/opportunity) for a set of statements. All the questions with a scale for answers were seven-level built and therefore, when grouped by meaning, the responses to them may be summed up (Carifi, 2007). It is crucial for the further statistical analysis of the data. In addition, the respondents were offered to assess their writing and oral foreign language skills separately for each foreign 
language they speak (second part of the questionnaire) based on the seven-level scale. The proficiency in a corporate language of each respondent was self-assessed according to the scale described above. After that, for each respondent, an average (arithmetical mean) of oral and writing skills in each foreign language they speak was calculated, and for further analysis the data was categorized into two groups according to the level of proficiency: 1) mean and over the mean (considered as 'high language skills'); and 2) lower than the mean (considered as 'low language skills'). Among all corporate languages that were mentioned by the respondents from Russia, the most common was English (73\%), followed by German (6\%), French (3.5\%) and Spanish (3\%), which were all decided to be included in the analyzed sample.

Overall, 1100 people have received the invitation, and 253 properly filled in the survey making a response rate of $21 \%$. They all were accepted for further analysis.

The chosen empirical model suggested looking at career mobility from three dimensions - vertical and horizontal, internal and external, and physical and psychological (Jokinen et al., 2011). Thus, different levels of corporate language skills of employees working in MNCs were tested to have an influence on all three dimensions of mobility. Measures and variables used in the questionnaire were justified and reliability and validity of them were proved.

The reliability of the measures used in the questionnaire to analyze the most difficult type of career mobility - perceived - will be proved using a Cronbach's alpha, a coefficient of internal consistency. We also prove our empirical method by analysis of previous researches. There are some qualitative case analyses previously made by several researchers (see, e.g. Bellak, 2010; Nousiainen, 2011; Piekkari et al., 2005) which propose ideas concerning the relationship between corporate language and career mobility in MNCs. There is also one quantitative study (Jokinen et al., 2011) proposing a theoretical model of this relationship. The Cronbach's alpha shows that internal consistency in the sets of items is good $(.8 \leq \alpha<0.9)$ and acceptable $(.7 \leq \alpha<0.8)$, which proves the reliability and validity of the measures used to estimate psychological mobility.

\section{Results and discussion}

First, the influence of different levels of corporate language skills on respondents' perceived preparedness for four types of career mobility is analyzed (Table 1 ).

For all four types of mobility, the respondents with better corporate language skills perceive that they have better preparedness to make a career move than the respondents with weaker corporate language skills (all means of respondents with better skills are higher than the means of those with lower skills). This relation is especially strong for vertical career mobility (for $\mathrm{p}<0.0001$ - very high level of significance) and external career mobility (for $\mathrm{p}<0.01$ ), which is statistically proved using a t-test for respective hypotheses. At the same time, there is no statistical significance in the relations between corporate language skills and horizontal career mobility, and corporate language skills and internal career mobility. As a result of the analysis, proposition 1 and proposition 4 were supported while proposition 2 and proposition 3 were not supported as they did not show statistical significance.

While the results for vertical career mobility were quite expected, since it is logical to assume that if an individual does not possess sufficient corporate language skills, it would be more difficult for them to move up the career ladder, the results for horizontal and external mobility were a bit surprising. The results for external career mobility in Russia also make for further consideration: why a better competence in corporate language makes the respondents feel more confident about their career not only inside but also outside their current organization, and that insufficiency in corporate language acts furthermore as a glass wall.

Therefore, the first data analysis proves the assumption that corporate language may act as a 'glass ceiling' (and a 'glass wall') for employees, who do not possess sufficient corporate language skills, and thus psychologically preventing their career mobility. For MNCs in Russia this glass ceiling especially prevents employees' perceived vertical and external mobility.

To analyze the actual vertical career mobility of the employees in international organizations depending on their corporate language skills, different levels of job positions inside the company could be taken into account as criteria. Table 2 depicts the absolute numbers and percentage frequencies of respondents' positions, both overall and according to a level of corporate language skills.

It can be observed that there is no strong relation between corporate language skills and respondents' positions in MNCs in Russia. Respondents with both, lower and higher corporate language skills take positions at all levels according to the frequencies in Table 2. Starting from the highest position level, there is a $30.4 \%$ : $69.6 \%$ proportion of top managers with weaker and better language levels respectively, which is quite surprising, since for the lower positions, such as clerical ones, the same proportion is $34.1 \%$ : $65.9 \%$ and for middle management it is $24.6 \%$ : $75.4 \%$, which is not so far from the proportion of top management as was expected. At the same time, at the higher position of 'experts' not so many employees with weaker language skills (20\%) as with higher skills (80\%) are reported. If we are to look at the percentages of the total sample, again, there is no evidence of corporate language influence on the job positions, as for all four positions the figures do not differ much: top management ( $12.7 \%$ vs. $12.2 \%)$, middle management (29.1\% vs. $37.4 \%$ ); experts (3.6\% vs. $6.1 \%$ ); and clerical positions (54.5\% vs. $44.2 \%$ ). As for an average number of promotions within the respondents of two groups, it also does not give a reason to assume the presence of influence of corporate language, since there is no significant difference between the 1.53 and 1.74 average numbers of promotions among employees with lower and higher language skills, respectively. Finally, the chi-square test (even for $\mathrm{p}<0.1$ ) did not reject proposition 5 as the supported proposition for MNCs in Russia, confirming the absence of a statistically significant difference in positions for employees with higher and lower competence in corporate language.

It was figured out that there is no significant dependence between corporate language skills and actual career mobility based on current positions of employees in MNCs in Russia. Although the data was analyzed carefully, the results might be slightly distorted by the low age of respondents and consequently the low duration of their career, meaning that it is still possible that in their future career, corporate language skills may enable or disable their career mobility.

Analyzing the further actual career mobility of respondents, Table 3 depicts the number and percentage of employees with a certain level of corporate language skills depending on the corporate language of the company they work in. It will help to check the actual internal career mobility. This relationship was checked also to indicate that the common corporate language will not attract more employees with matching language competences than those employees without them.

The analysis of the data shows that a clear relationship between the corporate language of companies and the foreign language skills of employees working in them exists. The overwhelming majority of respondents $(89.8 \%)$ reported that they possess highlevel skills in the corporate language (or corporate languages) of their employer, and only $10.2 \%$ indicated that their corporate language skills are not sufficient. Companies with English as a 
Table 1

Career mobility according to a level of corporate language skills.

\begin{tabular}{|c|c|c|c|c|c|c|c|c|}
\hline \multirow[t]{2}{*}{ Russian sample } & \multicolumn{6}{|c|}{ Corporate language skills } & \multirow[t]{4}{*}{ t-value } & \multirow[t]{4}{*}{ Sig. } \\
\hline & Sampl & & High & & Low & & & \\
\hline \multirow[t]{2}{*}{ Preparedness for ... } & \multicolumn{2}{|c|}{$\mathrm{n}=207$} & \multicolumn{2}{|c|}{$\mathrm{n}=144$} & \multicolumn{2}{|c|}{$\mathrm{n}=63$} & & \\
\hline & Mean & s.d. & Mean & s.d. & Mean & s.d. & & \\
\hline Vertical career mobility & 4.79 & 1.08 & 4.86 & 1.09 & 4.26 & .89 & 4.205 & $* * * *$ \\
\hline Horizontal career mobility & 4.69 & 1.04 & 4.76 & 1 & 4.21 & 1.24 & 2.283 & - \\
\hline Internal career mobility & 4.83 & 1.09 & 4.86 & 1.07 & 4.57 & 1.2 & 1.767 & - \\
\hline External career mobility & 4.7 & 1.04 & 4.78 & 1 & 4.07 & 1.14 & 3.598 & $* *$ \\
\hline
\end{tabular}

Level of significance: ${ }^{*} .05$ level ${ }^{* *} .01$ level ${ }^{* * *} .001$ level ${ }^{* * * *} .0001$ level.

Table 2

Positions of respondents according to a level of corporate language.

\begin{tabular}{|c|c|c|c|c|}
\hline \multirow[t]{2}{*}{ Russian sample } & & \multicolumn{2}{|c|}{$\begin{array}{l}\text { Level of } \\
\text { language }\end{array}$} & \multirow[t]{2}{*}{ Total } \\
\hline & & Low & High & \\
\hline \multirow[t]{3}{*}{ Clerical } & Count & 30 & 58 & 88 \\
\hline & $\%$ of total & $54.5 \%$ & $44.2 \%$ & $47.3 \%$ \\
\hline & $\%$ within group & $34.1 \%$ & $65.9 \%$ & \\
\hline \multirow[t]{3}{*}{ Expert } & Count & 2 & 8 & 10 \\
\hline & $\%$ of total & $3.6 \%$ & $6.1 \%$ & $5.4 \%$ \\
\hline & $\%$ within group & $20 \%$ & $80 \%$ & \\
\hline \multirow[t]{3}{*}{ Middle management } & Count & 16 & 49 & 65 \\
\hline & $\%$ of total & $29.1 \%$ & $37.4 \%$ & $34.9 \%$ \\
\hline & $\%$ within group & $24.6 \%$ & $75.4 \%$ & \\
\hline \multirow[t]{3}{*}{ Top management } & Count & 7 & 16 & 23 \\
\hline & $\%$ of total & $12.7 \%$ & $12.2 \%$ & $12.4 \%$ \\
\hline & $\%$ within group & $30.4 \%$ & $69.6 \%$ & \\
\hline \multirow[t]{2}{*}{ Total } & Count & 55 & 131 & 186 \\
\hline & $\%$ & $100.0 \%$ & $100.0 \%$ & $100.0 \%$ \\
\hline Average number of promotions & & 1.53 & 1.74 & 1.68 \\
\hline
\end{tabular}

$\chi^{2}(\mathrm{df}=3, \mathrm{n}=186)=4.269$, for $\mathrm{p}<0.1$.

Table 3

Correspondence of corporate language of a company and corporate language skills level of employees.

\begin{tabular}{|c|c|c|c|c|c|c|}
\hline \multirow{4}{*}{$\begin{array}{l}\text { Russian sample } \\
\text { Corporate language }\end{array}$} & \multicolumn{6}{|c|}{ Corporate language skills } \\
\hline & \multirow{2}{*}{\multicolumn{2}{|c|}{$\frac{\text { Sample }}{n=215}$}} & \multirow{2}{*}{\multicolumn{2}{|c|}{$\frac{\text { Low }}{n=22}$}} & \multirow{2}{*}{\multicolumn{2}{|c|}{$\begin{array}{l}\text { High } \\
\mathrm{n}=193\end{array}$}} \\
\hline & & & & & & \\
\hline & Count & $\%$ & Count & $\%$ & Count & $\%$ \\
\hline English & 183 & $85.1 \%$ & 16 & $8.7 \%$ & 167 & $91.3 \%$ \\
\hline German & 15 & $7.0 \%$ & 4 & $26.6 \%$ & 11 & $73.4 \%$ \\
\hline French & 9 & $4.2 \%$ & 1 & $11.1 \%$ & 8 & $88.9 \%$ \\
\hline Spanish & 8 & $3.7 \%$ & 1 & $12.5 \%$ & 7 & $87.5 \%$ \\
\hline Total & 215 & $100.0 \%$ & 22 & $10.2 \%$ & 193 & $89.8 \%$ \\
\hline
\end{tabular}

$\chi 2(\mathrm{df}=3, \mathrm{n}=215)=113.1$, for $p<0.0001$.

corporate language seem to attract slightly more employees competent in English (91.3\%). It is logical, since English is an official language in the business world, and increasing numbers of companies in Russia are establishing language requirements for applicants. Russian language was not included in the discussion in this part of the analysis as all the respondents reported Russian as their mother tongue, thus having the highest level of this language skill and eliminating any opportunity to compare skills levels. A chisquare test also rejected the hypothesis with a high level of significance $(\mathrm{p}<0.0001)$ for MNCs in Russia.

In conclusion to this data analysis and findings part, there is evidence that corporate language has its influence on the career mobility of employees in MNCs in Russia. This influence is proved, however, not in all cases - corporate language appeared to affect perceived vertical and external career mobility. In practice, employees from MNCs in Russia were not proved to have faced this glass ceiling because of corporate language skills meaning that there are probably some other and more important factors influencing their actual vertical career mobility. Moreover, it was found and statistically proven that for MNCs in Russia corporate language has a significant influence on the actual internal mobility of employees as an overwhelming majority of them prefer to work in organizations in which corporate language strategy matches their own language skills.

\section{Conclusion}

The study shows that corporate language has broad influences and implications in the Russian context. We aimed at investigating the influence of corporate language - a special managerial tool used by a large number of international companies in the present day - on career mobility of employees in MNCs in Russia. The importance of language competence for individuals' career success, and the ways in which language competence affects this, is a limited researched area, with only a few studies as an exception (Piekkari, 2008; Traavik \& Richardsen, 2010). While academics examining the corporate language phenomenon have not paid a great deal of attention to career issues, corporate language has not usually been considered as being one of the career mobility factors for researchers studying careers, especially in the Russian context. With respect to human capital theory, our results show how corporate language may act as a barrier and as a facilitator for career mobility of employees, in Russian MNCs, who have different levels of corporate language skills. From an employee's perspective, understanding how human capital development is associated with career perceptions may allow them to take a more proactive role in developing their language skills.

Whereas the positive impact of language on careers has been recognized in previous studies (e.g. Jokinen, 2010), its role as a barrier for careers has not. The findings of the current study demonstrate that a corporate language not only may play the role of a glass ceiling for the vertical mobility of employees but it also acts as a glass wall to horizontal career moves.

The analysis shows that corporate language actually acts not only as a glass ceiling but also as a glass wall for the career mobility of those employees whose corporate language skills are not sufficient. Employees, in MNCs in Russia, with weaker corporate language skills appeared to feel less confident and feel less prepared to make a career move than those with better language skills. At the same time, the dependence of actual vertical career mobility on corporate language skills was not statistically significant for employees working in MNCs in Russia. Finally, the analysis proved that there is a strong influence of the existing corporate language in a firm in attracting employees with a language fit, which is precisely internal career mobility.

The results of the research have several theoretical and 
empirical contributions, concerning three main aspects of the paper: namely, corporate language issues as a part of human capital, career mobility issues, and the Russian context. The findings prove the importance of considering language skills as an aspect of individuals' human capital that can explore significant career success-related issues, as argued by Becker (1975), Tietze (2008), and Traavik and Richardsen (2010). During the two recent decades, at least, academics have been studying the effects that corporate language has on the life of multinationals (Feely \& Harzing, 2004), including the coordination of communication, organizational power and control, internal and external communication, knowledge transfer, exporting, etc. - only few works touched on its effect on IHRM, in particular on career development. More specifically, our results extend the relatively new trend in international management and HRM research that proves the importance of language (Piekkari, 2008; Piekkari \& Zander, 2005) and the ability to analyze human capital issues in organizations, namely employees' career mobility from a linguistic competencies' perspective.

Furthermore, this research looks at career mobility from three different dimensions, out of which one dimension (physical and psychological mobility) is a unique topic in recent papers. Academics do not tend to examine it because of an ambiguous understanding and thus difficulties in the analysis of perceived (psychological) career mobility, especially through a language lens. We, among others (Jokinen et al., 2011), developed a set of items in order to assess this kind of mobility which can be used in further researches on this topic and statistically proved the consistency of it. Discussing career issues through linguistic perspectives we contribute also to career literature (Arthur et al., 2005; $\mathrm{Ng}$ et al., 2005; Sullivan \& Arthur, 2006), showing that career mobility is dependent on a greater number of factors and can be analyzed from a human theory perspective.

It is important to note that the research is one of the first attempts devoted to corporate language issues in connection with career development in the Russian context. There are very few researches on language issues for international organizations in developing countries, particularly in Russia, and none of them have investigated the corporate language effect on career mobility in Russian firms. Furthermore, the results gather the diverse ideas about the effect of corporate language on career mobility from different case-based studies in one theoretical model and tests this model based on a large set of quantitative data. According to the literature review, the existing base of academic studies on the topic is full of studies based on cases of one or several companies. This research generalizes these ideas and presents the results applied to a large quantity of MNCs in Russia. Moreover, the current paper is the other research that checks a conceptual model just recently proposed by Jokinen et al. (2011) and provides specific results for it.

The results allow for making some managerial implications for IHRM in several aspects such as overall corporate language strategy and policies in a company, as well as recruitment, retention, promotion and employee development. This study proves and shows how corporate language may influence perceived and actual career mobility. However, the results of the study should make HR managers adjust some of their practices according to the influence of corporate language on career mobility in their organizations; in particular, this study proves an even greater importance for corporate language training as a human capital development tool. The results argue that employees with higher corporate language skills feel more confident about their career mobility that those with lower corporate language skills, which may negatively affect the career development of the latter since they would not even try to initiate a career move because of insufficient language skills. This fact may cause the situation in which employees remain in their current positions, even though their professional skills allow them to move upward. Also it may cause the discrimination of a group of employees with weaker corporate language skills when making recruitment, performance appraisal and promotions. As for recruitment, an establishment of official corporate language requirements for candidates (if the company still does not have them) will help not only to increase the level of corporate language competence in a company but also to facilitate the internal communication, which is already proved to be an important factor for achieving corporate success. At the same time, corporate language training may replace these requirements by widening the pool of applicants and allowing for application to a company by those highly professional candidates who would not apply if language requirements existed. The study also shows that in MNCs in Russia top management does not have an advantage in corporate language knowledge in comparison with other levels of positions. While for such positions as clerical or middle management corporate language skills are highly desirable, but for top management they are obligatory by definition of corporate language. Insufficient competence in the corporate language among top managers may cause communication problems at the very highest level. HR managers should pay more attention to this potential problem and probably organize corporate language training for this level of positions.

Setting the ground for further research and limitations, we argue that the study is not industry specific, respondents are representing companies from many different spheres of business, thus the analysis shows general results, yet results might vary for each specific industry. As the research tests a conceptual model of corporate language influencing career mobility, further researches can be further focused at firm level, investigating one (or several) specific company and, with the help of in-depth interviews and other methods of qualitative research, apply the model exactly to it, in order to examine more deeply the connections and relations and thus develop conclusions and recommendations for IHRM for a specific case. This could also solve the issue of no industry specification. Besides, for the assessment of internal communication of an IHRM department with the other departments within a company it could be interesting to compare and discuss answers on the topic of corporate language influence on the career perception of HR managers, and other employees, and their vision of corporate language strategy and of the implementation of this strategy. Moreover, comparative research including pan-country analysis may be of the highest interest in the future, also leaving room for the analysis of language issues from sociological and psychological perspectives.

\section{Acknowledgements}

The authors gratefully acknowledge the financial support granted by the Foundation for Economic Education, and the support of the Center for the Study of Emerging Market and Russian Multinational Enterprise (project ID 15.61.172.2015).

\section{References}

Andersen, H., \& Rasmussen, E. (2002). The role of language skills in corporate communication. Paper for the Nordic Workshop on Inter-organizational Research, 12.

Arthur, M. B., Khapova, S. N., \& Wilderom, C. P. M. (2005). Career success in boundaryless world. Journal of Organizational Behavior, 26, 177-202.

Barnett, W. P., \& Miner, A. S. (1992). Standing on the shoulders of others: career independence in job mobility. Administrative Science Quarterly, 37(2), 62-81.

Baruch, Y. (2006). Career development in organizations and beyond: balancing traditional and contemporary viewpoints. Human Resource Management Review, 16, 125-138.

Baruch, Y., Grimland, S., \& Vigoda-Gadot, E. (2014). Professional vitality and career success: mediation, age and outcomes. European Management Journal, 32(3), $518-527$. 
Becker, G. S. (1975). Human capital. Chicago, IL: University of Chicago Press.

Bellak, N. (2010). The role of language(s) in business: three Danish cases and their corporate language policies. In Copenhagen, Denmark, ICIC'10, 19-20 (pp. 207-210).

Bjorkman, A., \& Piekkari, R. (2009). Language and foreign subsidiary control: an empirical test. Journal of International Management, 15, 105-117.

Blazejewski, S. (2006). Transferring value-infused organizational practices in multinational companies: a conflict perspective. In M. Geppert, \& M. Mayer (Eds.), Global, national and local practices in multinational corporations. Houndmills: Palgrave Macmillan.

Bloch, B. (1995). Career enhancement through foreign language skills. The International Journal of Career Management, 7(6), 15-26.

Briscoe, J. P., \& Finkelstain, L. M. (2009). The «new career» and organizational commitment: do boundaryless and protean attitudes make a difference? Career development international, 14(3), 242-260.

Briscoe, J. P., Hall, D., \& Frautschy DeMuth, R. (2006). Protean and boundaryless career: an empirical exploration. Journal of Vocational Behavior, 69, 30-47.

Briscoe, J. P., Henagan, S. C., Burton, J. P., \& Murphy, W. M. (2012). Coping with an insecure employment environment: the differing roles of protean and boundaryless career orientations. Journal of Vocational Behavior, 80, 308-316.

Buckley, P., Carter, M., Clegg, J., \& Tan, H. (2005). Language and social knowledge in foreign-knowledge transfer to China. International Studies of Management \& Organization, 35(1), 47-65.

Carifi, P. (2007). Ten common misunderstandings, misconceptions, persistent myths and urban legends about Likert scales and Likert response formats and their antidotes. Journal of Social Sciences, 3(3), 106-116.

Charles, M. (2006). Language matters in global communication. Journal of Business Communication, 44(3), 260-282.

Charles, M., \& Marschan-Piekkari, R. (2002). Language training for enhanced horizontal communication: a challenge for MNCs. Business Communication Quarterly, 65(2), 9-29.

Clarke, W. M. (2000). The use of foreign languages by Irish exporters. European Journal of Marketing, 34(1), 80.

Crick, D. (1999). An investigation into SMEs' use of languages in their export operations. International Journal of Entrepreneurial Behavior \& Research, 5(1), 19-31.

Cromie, C., Clarke, B., \& Cromie, S. (1997). The use of foreign languages by Irish exporters. Irish Journal of Management, 18, 16-33.

DeFillippi, R. J., \& Arthur, M. B. (1994). The boundaryless career: a competencybased perspective. Journal of Organizational Behavior, 15, 307-324.

Dobrey, S. (2005). Career mobility and job flocking. Social Science, 34, 800-820.

Eby, T., Butts, M., \& Lockwood, A. (2003). Predictors of success in the era of the boundaryless career. Journal of Organizational Behavior, 24, 689-708.

Ehrenreich, S. (2010). English as business lingua franca in a German MNC. Journal of Business Communication, 47(4), 408-431.

Evans, P., Pucik, V., \& Björkman, I. (2011). The global challenge: International human resource management. New York: McGraw-Hill.

Feely, A., \& Harzing, A.-W. (2003). Language management in multinational companies. Cross Cultural Management, 10(2), 37-52.

Feely, A., \& Harzing, A.-W. (2004). Language barrier and its implications for HQsubsidiary relationships. In Presented at the 2004 AOM Conference, New Orleans 6-11 August.

Feldman, D. C., \& Ng, T. W. H. (2007). Career: mobility, job embeddedness, and success. Journal of Management, 33, 350-377.

Filippov, S. (2009). Russia's emerging multinationals. Journal of Strategic Management Education, 5(3\&4), 167-186.

Forrier, A., Sels, L., \& Stynen, D. (2009). Career mobility at the intersection between agent and structure: a conceptual model. Journal of Occupational and Organizational Psychology, 2(4), 739-759.

Fredriksson, R., Barner-Rasmussen, W., \& Piekkari, R. (2006). The multinational corporation as a multilingual organisation: the notion of a common corporate language. Corporate Communications: An International Journal, 11(4), 406-423.

Gunz, H., \& Peiperl, M. (2007). Handbook of career studies. Sage publications, Inc.

Hegedus, D. M., \& Haman, E. A. (1992). Patterns and outcomes of individual career mobility for Wisconsin school administrators. Journal of Vocational Behavior, 40, 82-94.

Hege, A., \& Ralston, D. (1993). Managerial career progression and aspiration: evidence of a glass ceiling? International Journal of Employment Studies, 1(2), $253-282$.

Henderson, J. K. (2005). Language diversity in international management teams. International Studies of Management and Organizations, 35(1), 66-82.

Huang, L., Frideger, M., \& Pearce, J. L. (2014). How non-native speakers can crack the glass ceiling. Harvard Business Review. https://hbr.org/2014/06/how-nonnative-speakers-can-crack-the-glass-ceiling. June 1.

Ibarra, H. (2002). How to stay stuck in the wrong career. Harvard Business Review, $80(12), 8-40$.

Ituma, A., \& Simpson, R. (2009). The boundaryless career and career boundaries: applying an institutional perspective to ICT workers in the context of Nigeria. Human Relations, 62(5), 709-719.

Jokinen, T. (2010). Development of career capital through international assignments and its transferability to new contexts. Thunderbird International Business Review, 52(4), 325-336.

Jokinen, T., Järlström, M., \& Piekkari, R. (2011). Career mobility in international organizations: language as a glass ceiling to upward mobility? In Proceedings of European International Business Academy (EIBA). Conference 2011, Bucharest,
Romania.

Judge, T. A., Cable, D. M., Boudreau, J. W., \& Bretz, R. D. (1995). An empirical investigation of the predictors of executive career success. Personnel Psychology, $48,485-519$.

Judge, T. A., \& Hurst, C. (2008). How the rich (and happy) get richer (and happier): relationship of core self-evaluations to trajectories in attaining work success. Journal of Applied Psychology, 93, 849-863.

Khapova, S. N., Arthur, M. B., Wilderom, C. P. M., \& Svensson, J. S. (2007). Professional identity as a key to career change intention. Career Development International, 12(7), 584-595.

Klevtsova, V. (2008). The peculiarities of English language training for personnel Management of Personnel Development, 4(16).

Ku, H., \& Zussman, A. (2010). Lingua franca: the role of English in international trade. Journal of Economic Behavior \& Organization, 75, 250-260.

Lauring, J., \& Selmer, J. (2011). Multicultural organizations: common language, knowledge sharing and performance. Personnel Review, 40(3), 324-343.

Lazarova, M., \& Taylor, S. (2009). Boundaryless career, social capital, and knowledge management: implications for organizational performance. Journal of Organizational Behavior, 30(1), 119-139.

Likert, R. (1932). A technique for the measurement of Attitudes. Archives of Psychology, 140, 1-55.

Littleton, S. B., Arthur, M. B., \& Rousseau, D. M. (2000). The future of boundaryless careers. In A. Collin, \& R. A. Young (Eds.), The future of career. Cambridge: Cambridge University Press.

Lönnholm, M. (2012). A language competence and subjective career success: A study of international business managers in Finland. Master thesis. Hanken School of Economics.

Luo, Y., \& Shenkar, O. (2006). The multinational corporation as a multilingual community: language and organization in a global context. Journal of International Business Studies, 37(3), 321-339.

Makela, K., Kalla, H., \& Piekkari, R. (2007). Interpersonal similarity as a driver of knowledge sharing within multinational corporations. International Business Review, 16, 1-22.

Marler, J., Barringer, M., \& Milkovich, G. (2003). Boundaryless and traditional contingent employees: worlds apart. Journal of Organizational Behavior, 23, 425-453.

Marschan-Piekkari, R., Welch, D., \& Welch, L. (1999a). Adopting a common corporate language: IHRM implications. International Journal of Human Resource Management, 10(3), 377-390.

Marschan-Piekkari, R., Welch, D., \& Welch, L. (1999b). In the shadow: the impact of language on structure, power and communication in the multinational. International Business Review, 8(4), 421-440.

Marschan, R., Welch, D., \& Welch, L. (1997). Language: the forgotten factor in multinational management. European Management Journal, 15(5), 591-598.

Muukari, K. (2008). The influence of language competence on individuals' career paths in a MNC. Pro Gradu. Faculty of International Business, Helsinki School of Economics.

Newburry, W., \& Thakur, P. (2010). Multilevel impact on perceived career opportunity from global integration: human capital development within interna institutional environments. The International Journal of Human Resource Management, 21(13), 2358-2380.

Ng, T. W. H., Eby, L. T., Sorensen, K. L., \& Feldman, D. C. (2005). Predictors of objective and subjective career success: a meta-analysis. Personnel Psychology, 58, 367-408.

Nousiainen, A. (2011). The relationship between language and careers in multinational corporations: A case study of UPM-KymmeneOyj. MSc thesis. Faculty of International business, Aalto University School of Economics.

Panibratov, A. (2012). Russian multinationals: From regional supremacy to global lead. London, New York: Routledge.

Peltonen, T. (1993). Managerial career patterns in transnational corporations: an organizational capability approach. European Management Journal, 11(2), $248-257$.

Peluchette, J. V. (1993). Subjective career success: the influence of individual difference, family and organizational variables. Journal of Vocational Behavior 42(2), 198-208.

Piekkari, R. (2008). In S. Tietze (Ed.), International management and language. Routledge Chapman \& Hall.

Piekkari, R., Vaara, E., Tienari, J., \& Säntti, R. (2005). Integration or disintegration? human resource implications of the common corporate language decision in a cross-border merger. International Journal of Human Resource Management, 16(3), 333-347.

Piekkari, R., \& Zander, L. (2005). Language and communication in international management. International Studies of Management \& Organization, 35(1), 1-9.

Plessis, A., \& Huntley, K. (2009). Challenges in a globalized context for IHR managers in South African organizations. International Review of Business Research Papers, 5(1), 413-427.

Pohjanen, K., \& Talja, K. (2011). Language strategies in Finnish small and mediumsized enterprises. MSc thesis. Department of Management and International Business. Aalto University, School of Economics.

SanAntonio, P. M. (1987). Social mobility and language use in an American company in Japan. Journal of Language and Social Psychology, 6(3-4), 191-200.

Seibert, S. E., Kraimer, M. L., \& Liden, R. C. (2001). A social capital theory of career success. Academy of Management Journal, 44, 219-237.

Shanahan, D. (1996). From language learner to multicultural manager. European Management Journal, 14(3), 315-320. 
Sorensen, E. S. (2005). Our corporate language is English: An exploratory survey of 70 DK-sited corporations' use of English. MSc thesis. Aarhus: Faculty of Language and Business Communication, Aarhus School Business.

Sullivan, S. E., \& Arthur, M. B. (2006). The evolution of the boundaryless career concept: examing physical and psychological mobility. Journal of Vocational Behavior, 69, 19-29.

Swift, J. S. (1991). Foreign language ability and international marketing. European Journal of Marketing, 25(12), 36-49.

Terjesen, S., Hinger, J. Tenzer, H., \& Harzing, A.-W. (2014). Language in management research: a review and agenda for future research. In Paper presented at the 40th EIBA (European International Business Academy) Conference, Uppsala, 11-13 December.

Tietze, S. (2008). International management and language. London: Routledge.

Traavik, L. E. M., \& Richardsen, A. M. (2010). Career success for international professional women in the land of the equal? evidence from Norway. The
International Journal of Human Resource Management, 21(15), 2798-2812. Trochim, W. M. (2002). Likert scaling. Research methods knowledge base (2nd ed.). Turnbull, P. W., \& Welham, G. F. (1985). The characteristics of European export marketing staff. European Journal of Marketing, 19(2), 31-41.

Vaara, E., Piekkari, R., \& Santti, R. (2005). Language and the circuits of power in a merging multinational corporation. Journal of Management Studies, 42, 3.

Verbrugge, M. (2012). Psychological mobility and career success in the «New» career climate. Journal of Vocational Behavior, 81(2), 289-297.

Welch, D., \& Welch, L. (2008). The importance of language in international knowledge transfer. Management International Review, 48(3), 339-360.

Welch, L., Welch, D., \& Piekkari, R. (2005). Speaking in tongues: the importance of language in international management processes. International Studies of Management and Organization, Special Issue on Language and Communication in International Management, 35(1), 10-27. 